\title{
PENYULUHAN GOOGLE CLASSROOM DAN GOOGLE MEET KEPADA GURU SDN WONOAYU DALAM KEGIATAN KKN BACK TO VILLAGE
}

\author{
Ihyana Lutfianda ${ }^{1,}$ Muhammad Bahrul Ulum² \\ Fakultas Teknik, Universitas Jember ${ }^{1}$, Fakultas Hukum Universitas Jember ${ }^{2}$ \\ ihlutfi215@gmail.com,muhd.bahrul@unej.ac.id
}

\begin{abstract}
The COVID-19 pandemic that has spread across all countries requires humans to avoid crowds, affecting students' learning activities in primary schools. SDN Wonoayu is located in the Pilangkenceng sub-district, Madiun district, carrying out online learning activities for the semester 2019/2020 using the Whatsapp group. The teachers of SDN Wonoayu had difficulty in recapitulating their assignments. Also, some parents faced the same, particularly their challenges in utilizing Whatsapp for their child's learning media and their business media. Students were less able to understand because of independent learning. It required direct interaction to study the material or practice memorization. This program was expected to assist in uploading material, implementing assignment collection, and assisting teacher assessments of students during learning at home using Google Classroom. The Google Form's features were used as a medium for quizzes so that the grades automatically could be easily recapitulated by teachers. Using Google Meet could help learning media for both students and teachers to interact virtually to review material or memorization practices. The work program was carried out with the following steps: introduction (observation and problem identification), looking for literature and information that would be used as additional learning media, counseling learning media to teachers according to health protocols, applying learning media to students, and mentoring teachers. In summary, this KKN program could meet success indicators of $>$ $70 \%$ based on questionnaire data given to Islamic Education Teachers, PJOK Teachers, and Grade 4 Student Samples.
\end{abstract}

Keywords: Learning Media, Google Classroom, Google Meet.

\begin{abstract}
ABSTRAK
Pandemi COVID-19 yang melanda dengan cepat ke semua negara mengharuskan manusia untuk menghindari kerumunan, yang juga berdampak terhadap siswa dalam kegiatan pembelajaran di sekolah dasar. SDN Wonoayu berada di kecamatan pilangkenceng kabupaten madiun, melaksanakan kegiatan pembelajaran semester genap 2019/2020 daring menggunakan media grup Whatsapp. Para guru SDN Wonoayu mengalami kesulitan dalam melakukan rekap tugas dan begitu juga beberapa wali murid yang intens menggunakan Whatsapp sebagai bisnis merasa kurang nyaman. Murid kurang bisa memahami karena belajar mandiri, membutuhkan interaksi secara langsung menelaah materi atau praktik hapalan. Program ini diharapkan dapat membantu dalam upload materi, pelaksanaan pengumpulan tugas dan membantu penilaian guru terhadap siswa-siswi selama
\end{abstract}


pembelajaran yang di lakukan di rumah menggunakan Google Classroom. Fitur Google forms digunakan sebagai media kuis dengan begitu nilai secara otomatis keluar dapat dengan mudah direkap guru. Penggunakan Google Meet dapat membantu media pembelajaran bagi murid kepada guru berinteraksi secara virtual untuk mereview materi atau praktik hafalan. Program kerja tersebut dilakukan dengan langkah-langkah berikut pengenalan (observasi dan identifikasi masalah), mencari literatur dan informasi yang akan digunakan sebagai tambahan media pembelajaran, penyuluhan media pembelajaran kepada guru sesuai protokol kesehatan, penerapan media pembelajaran kepada siswa dan pendampingan kepada guru. Secara keseluruhan program KKN ini dapat memenuhi indikator keberhasilan sebesar $>70 \%$ berdasarkan data kuesioner yang diberikan kepada Guru PAI, Guru PJOK, Sampel Siswa Kelas 4.

Kata Kunci : Media Pembelajaran, Google Classroom, Google Meet.

\section{PENDAHULUAN}

Coronavirus Disease 2019 (COVID-19) yang melanda dengan cepat ke semua negara mengharuskan manusia untuk menghindari kerumunan, dengan banyak masyarakat disarankan untuk beraktivitas dari rumah. Selain itu, dalam hubungan sosial, masyarakat juga disarankan untuk menjaga jarak dan mematuhi protokol kesehatan sehingga mereka tidak dapat lagi melakukan aktivitas seperti biasanya, termasuk menuntut ilmu ke sekolah bagi siswa. Kegiatan pembelajaran untuk mencerdaskan kehidupan bangsa harus dilakukan dengan cara inovatif, salah satunya dengan melakukan proses belajar mengajar secara daring. Pembelajaran daring merupakan hal baru dan menjadi tantangan di dunia pendidikan termasuk bagi guru, siswa, dan wali murid.

Surat Edaran Menteri Pendidikan dan Kebudayaan Nomor 4 Tahun 2020 Tentang Pelaksanaan Kebijakan Pendidikan Dalam Masa Darurat Penyebaran Corona Virus Disease (Covid-19) merupakan salah satu bukti bersejarah bagi dunia pendidikan di negara Indonesia. Dalam surat edaran tersebut terdapat 6 poin penting yang tertuang didalamnya berkaitan dengan pelaksanaan pelaksanaan kebijakan pendidikan yang harus disikapi oleh kepala sekolah, guru, peserta didik, dan seluruh warga sekolah, yaitu 1) Pelaksanaan Ujian Nasional, 2) Proses Belajar dari Rumah, 3) Ujian Sekolah, 4) Kenaikan Kelas, 5) Penerimaan Peserta Didik Baru, dan 6) Dana Bantuan Operasional Sekolah. Kebijakan yang telah beredar menghasilkan banyak fenomena menarik bagi dunia pendidikan khususnya di Indonesia.

Pandemi dan belajar melalui sistem daring ini memberikan permasalahan terhadap dunia pendidikan, khususnya juga dirasakan oleh pendidikan di desa Wonoayu Kecamatan Pilangkenceng Kabupaten Madiun. Siswa dan orang tua Sekolah Dasar Negeri Wonoayu pada saat pandemi ini banyaj mengeluhkan kegiatan pedagogi yang berlangsung di masa pandemi karena dilaksanakan berbasis online. Terlebih, dalam pembelajaran berbasis online ini, diperlukan dua prasarana utama, yaitu smartphone dan kuota internet yang cukup untuk menunjang pembelajaran. Dalam kondisi seperti ini orang tua siswa menuturkan bahwa mereka ingin siswa kembali masuk seperti biasanya. Hal ini karena pada awalnya Kecamatan Pilangkenceng merupakan zona hijau namun pada Agustus 2020 berubah menjadi zona merah. Oleh karena itu, pembelajaran daring tetap harus dilaksanakan demi kesehatan bersama. Keluhan mengenai kuota internet seiring 
berjalannya waktu sudah terbiasa dengan pembelajaran daring. Di SDN ini, sebagian besar siswa mengalami permasalahan dalam segi pemahaman dan media pembelajaran.

Kegiatan pengabdian dalam program Kuliah Kerja Nyata (KKN) Back to Village 2020 oleh Universitas Jember ini bertujuan untuk memaksimalkan kontribusi sosial mahasiswa dalam penanganan COVID-19. Dalam program ini, mahasiswa terjun ke desa masing-masing dan mengambil peran dalam membantu menyelesaikan permasalahan di desa masing-masing. Dengan peran sebagai penggerak di tingkat akar rumput, kegiatan ini merupakan bentuk tanggung jawab sosial, moral dan intelektual perguruan tinggi dan mahasiswa terhadap masyarakat atas perubahan sosial di masa pandemicCOVID-19.

Berdasarkan hasil observasi dan pengamatan kepada sasaran, Sekolah Dasar Negeri Wonoayu, melaksanakan kegiatan pembelajaran semester genap 2019/2020 daring menggunakan media whatsapp grup. Kegiatan pembelajaran meliputi kegiatan penyampaian materi, mengerjakan buku Lembar Keja Siswa (LKS) dan dikumpulkan melalui whatsapp grup. Guru Sekolah Dasar Negeri Wonoayu mengalami kesulitan dalam melakukan rekap data tugas murid dan begitu juga beberapa wali murid yang intens menggunakan whatsapp sebagai bisnis merasa kurang nyaman. Murid kurang bisa memahami karena belajar mandiri, membutuhkan interaksi secara langsung mereview materi atau pertanyaan yang masih belum paham.

\section{METODE}

Kegiatan pengabdian kepada masyarakat (KKN) ini dilaksanakan mulai tanggal 01 Juli 2020 sampai dengan 14 Agustus 2020. Metode pelaksanaan yang digunakan untuk mencapai tujuan dari program kerja KKN 08 Back To Village Universitas Jember dengan tematik "Inovasi Pedukung Pembelajaran Anak Sekolah Saat Pandemi Covid-19" yaitu peningkatan pemahaman siswa melalui media pembelajaran daring. Perubahan penggunaan media pembelajaran daring dari whatsapp grup ke google classroom dan google meet dilaksanakan dengan beberapa tahap yang dilakukan setiap minggu, sebagai berikut :

\section{A. PERENCANAAN}

Dalam tahap perencanaan, mahasiswa KKN 08 Back To Village Universitas Jember 2020 melakukan identifikasi permasalahan dan observasi di SDN Wonoayu. Kegiatan wawancara dan sosialisasi program KKN dilaksanakan pada minggu pertama dengan guru, wali murid, dan kepala sekolah. Pada tahap ini memungkinkan terjadinya perubahan kecil terhadap program KKN yang semula direncanakan sesuai kondisi di lapangan. Penambahan program pendukung juga dilaksanakan untuk mendukung program KKN.

B. PELAKSANAAN

Pada tahap pelaksanaan, mahasiswa KKN 08 Back To Village Universitas Jember 2020 melakukan kegiatan penyuluhan kepada sasaran dilaksanakan secara langsung sesuai protocol kesehatan. Kegiatan penerapan dilaksanakan oleh sasaran selama tiga minggu secara bertahap. Peran mahasiswa KKN lebih ke pendampingan dan membantu pelaksanaan agar berjalan lancar dan sasaran dapat menguasai media pembelajaran daring yang diterapkan. 


\section{EVALUASI}

Pada tahap edukasi dan evaluasi, mahasiswa KKN 08 Back To Village Universitas Jember 2020 memberikan evalusi kegiatan dimana dilakukan setiap akhir kegiatan yang dilaksanakan untuk mengukur keberhasilan program pengabdian di Desa Sendiri.

\section{HASIL PEMBAHASAN}

Berdasarkan observasi sesuai dengan metode yang telah direncanakan, kegiatan program kerja KKN 08 Back To Village Universitas Jember 2020 di SDN Wonoayu telah terlaksana kegiatan :

A. TAHAP PERENCANAAN

Perencanaan dimulai menyusun kerangka program KKN sesuai dengan tematik "Inovasi Pendukung Pembelajaran Anak Sekolah Saat Covid-19“. Setelah karangka program KKN sudah jadi mahasiswa KKN 08 Back To Village Universitas Jember 2020 di SDN Wonoayu melakukan komunikasi dengan Kepala Sekolah untuk meminta dukungan dan izin dalam melakukan program KKN.

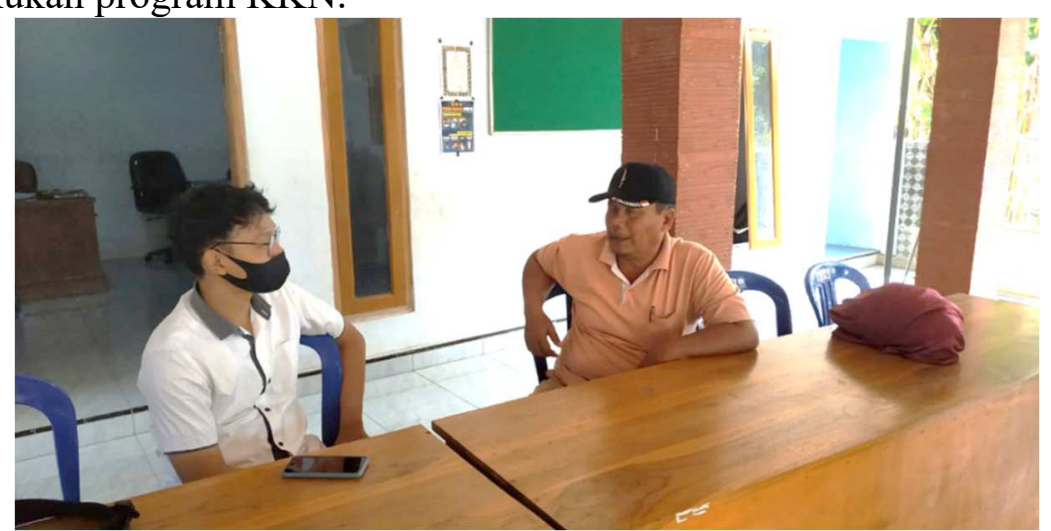

Gambar 1. Wawancara dengan Kepala Desa Wonoayu

Pengusulan karangka program KKN didiskusikan dengan Kepala sekolah Bapak Lamiyun dan Guru SDN Wonoayu mengenai konsep pelaksanaan. Berdasarkan hasil dari diskusi dengan Kepala sekolah Bapak Lamiyun dan Guru SDN Wonoayu, mahasiswa KKN 08 Universitas Jember 2020 diizinkan dan didukung untuk melakukan kegiatan penyuluhan kepada Guru SDN Wonoayu. Penerapan media pembelajaran daring google classroom dan google meet belum pernah dilaksanakan di SDN Wonoayu. Sehingga guru juga tertarik dan ingin mencoba menerapkan program KKN "Penyuluhan Google Classroom dan Google Meet Kepada Guru SDN Wonoayu".

\section{B. TAHAP PELAKSANAAN}

Penyuluhan dilaksankan oleh mahasiswa Back To Village 2020 di dalam kelas dan mematuhi protokol kesehatan dihadiri enam dari total delapan Guru SDN Wonoayu . Kegiatan ini dilaksanakan dalam dua sesi sesuai dengan media pembelajaran yang digunakan. Sesi pertama penyuluhan aplikasi google classroom dilaksanakan 30 menit pemaparan 
materi dan 90 menit untuk praktik bersama. Beberapa guru yang relatif muda dapat dengan cepat mengikuti praktik yang saya contohkan tetapi beberapa kesulitan karena kurang lihai faktor usia.

Sesi kedua penyuluhan aplikasi google meet dilaksankan 10 Menit pemaparan dan 20 menit praktik bersama. Membuat ruang rapat, mempresentasikan, dan membagikan link ruang rapat dapat dilaksanakan dengan mudah oleh semua guru. Meskipun terkadang terkendala sinyal WiFi yang agak lemot dan tertinggal langkah-langkah yang saya contohkan sesi pertama tetap berjalan lancar.

\section{DAFTAR IIADIR GURU SDN WONOAYU KEGIATAN PENYULUHAN GOOGLE CLASSROOM DAN GOOGLE MEET KKN BACK TO VILLAGE UNEJ 2020}

TEMPAT : SDN Wonoayu

TANGGAL: 15 Julı 2020

\begin{tabular}{|c|c|c|c|c|}
\hline No & NAMA & WALI KELAS/MAPEL & TANDA TAN & GAN \\
\hline 1 & SUROHO & WQL Kulas U. & $1\left(k_{x}=2\right)$ & \\
\hline 2 & SuJtnot & i. $T$ & 47 & 2 the \\
\hline 3 & ENI SRI WUILANDAR & 4 & 3 taieg & \\
\hline 4 & FRIMA LS & PJOK & & 4 tipr \\
\hline 5 & SITI NURJANAH & Guru Dhs. Sawa & 5 Sini & 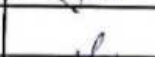 \\
\hline 6 & MINARSIH & wair kelas IV & $\sin ^{4}$ & 6 Q1f \\
\hline 7 & & & 7 & \\
\hline 8 & & & & 8 \\
\hline 9 & & & 9 & \\
\hline 10 & & & & 10 \\
\hline
\end{tabular}

Gambar 2. Daftar Hadir Guru SDN Wonoayu Keegiatan Penyuluhan Penerapan program KKN yang semula direncanakan untuk dilaksanakan oleh semua Guru SDN Wonoayu dirubah menjadi dua guru sasaran yaitu Guru PAI Ibu Eka Nur Farida Rahmawati,S.Pd.I dan Guru PJOK Bapak

Prima Luhung Saputro, S.Pd. Peggantian target sasaran dikarenakan beberapa Guru Wali Kelas kesulitan untuk menyesuaikan tematik dengan jadwal mingguan di google classroom. Selain itu, beberapa Guru Wali Kelas masih kurang begitu menguasi media pembelajaran dikarenakan factor usia berbeda dengan Guru PAI dan PJOK yang tergolong masih muda. Namun, berjalannya waktu Guru Wali Kelas terkadang juga ikut membantu dan berkoordinasi dengan Guru PAI dan PJOK. 


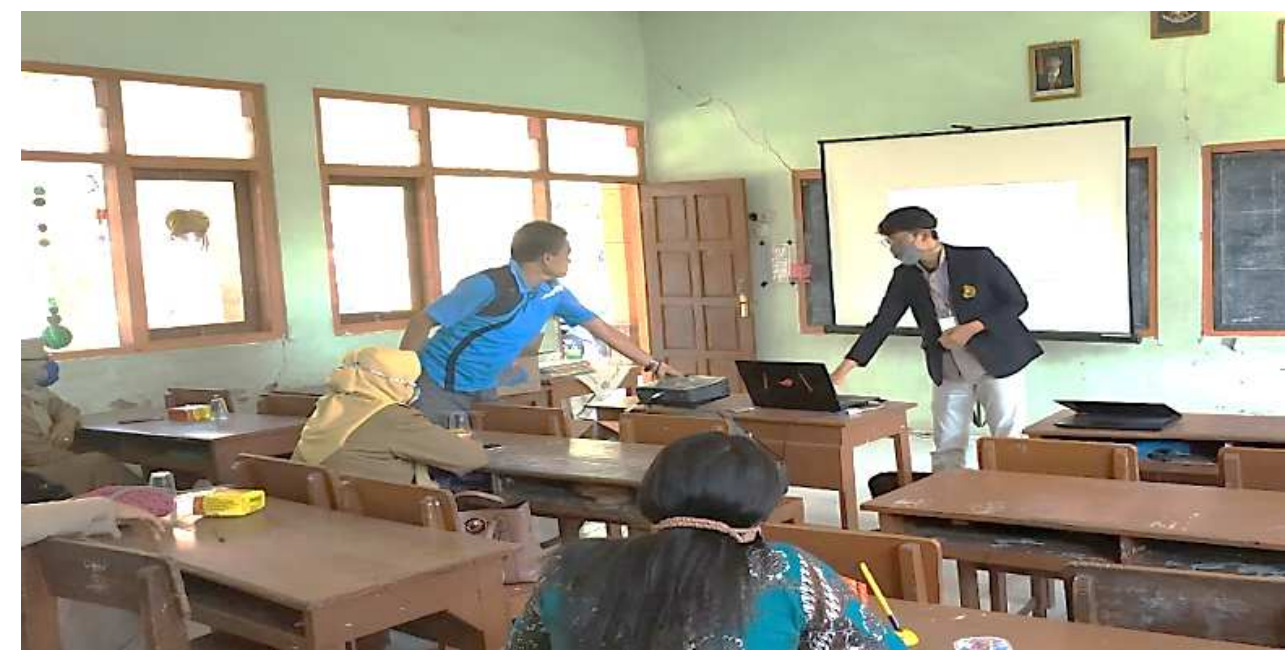

Gambar 3. Pelaksanaan Penyuluhan Google Classroom dan Google Meet Pada minggu pertama penerapan google classroom kelas sudah dibuat oleh Guru PAI dan PJOK. Mahasiswa KKN 08 Universitas Jember 2020 melakukan pendampingan untuk upload materi, membuat tugas, kuis di google forms dan merekap tugas. Hari pertama pendampingan upload materi, membuat tugas, di hari kedua pendampingan untuk menilai dan merekap tugas. Pelaksanaan google classroom ini dilaksanakan untuk

kelas 1-6 dengan jumlah siswa yang join kelas sebagai berikut :

Tabel 1. Tabel Jumlah Siswa yang Gabung Google Classroom

\begin{tabular}{|c|c|c|c|c|}
\hline No & Kelas & $\begin{array}{c}\text { Jumlah } \\
\text { Siswa }\end{array}$ & $\begin{array}{c}\text { Jumlah siswa } \\
\text { gabung google } \\
\text { classroom }\end{array}$ & $\begin{array}{c}\text { Prosentase siswa } \\
\text { gabung google } \\
\text { classroom }\end{array}$ \\
\hline 1 & Kelas I & 15 & 10 & $67 \%$ \\
\hline 2 & Kelas II & 17 & 4 & $23 \%$ \\
\hline 3 & Kelas III & 17 & 9 & $53 \%$ \\
\hline 4 & Kelas IV & 34 & 31 & $91 \%$ \\
\hline 5 & Kelas V & 29 & 14 & $48 \%$ \\
\hline 6 & Kelas VI & 30 & 31 & $100 \%$ \\
\hline
\end{tabular}

Siswa yang tidak bisa gabung google classroom dikarenakan keterbatasan kemampuan smartphone seperti memori tidak mencukupi, ram terlalu kecil menyebabkan lemot. Pengumpulan tugas dan upload materi bagi siswa yang tidak gabung di google classroom tetap dilaksanakan di whatsapp grup. Wali Kelas II sejak bulan Maret 2020 menerapkan sistem pemberian materi, pengumpulan tugas melalui paguyuban wali murid. Pengumpulan tugas dikumpulkan ke ketua paguyuban dan kemudian disetor ke Wali Kelas II di Sekolah. Sehingga pelaksanaan google classroom untuk Kelas II tidak maksimal, Guru PAI dan PJOK juga mengikuti system Wali Kelas II. Namun di minggu pertama penerapan google classroom ini Guru PAI dan PJOK sudah menguasai dan siswa juga sudah bisa download materi, upload tugas, dan mengerjakan kuis sesuai tutorial yang telah di unggah di youtube oleh Mahasiswa KKN 08 Universitas Jember 2020. 


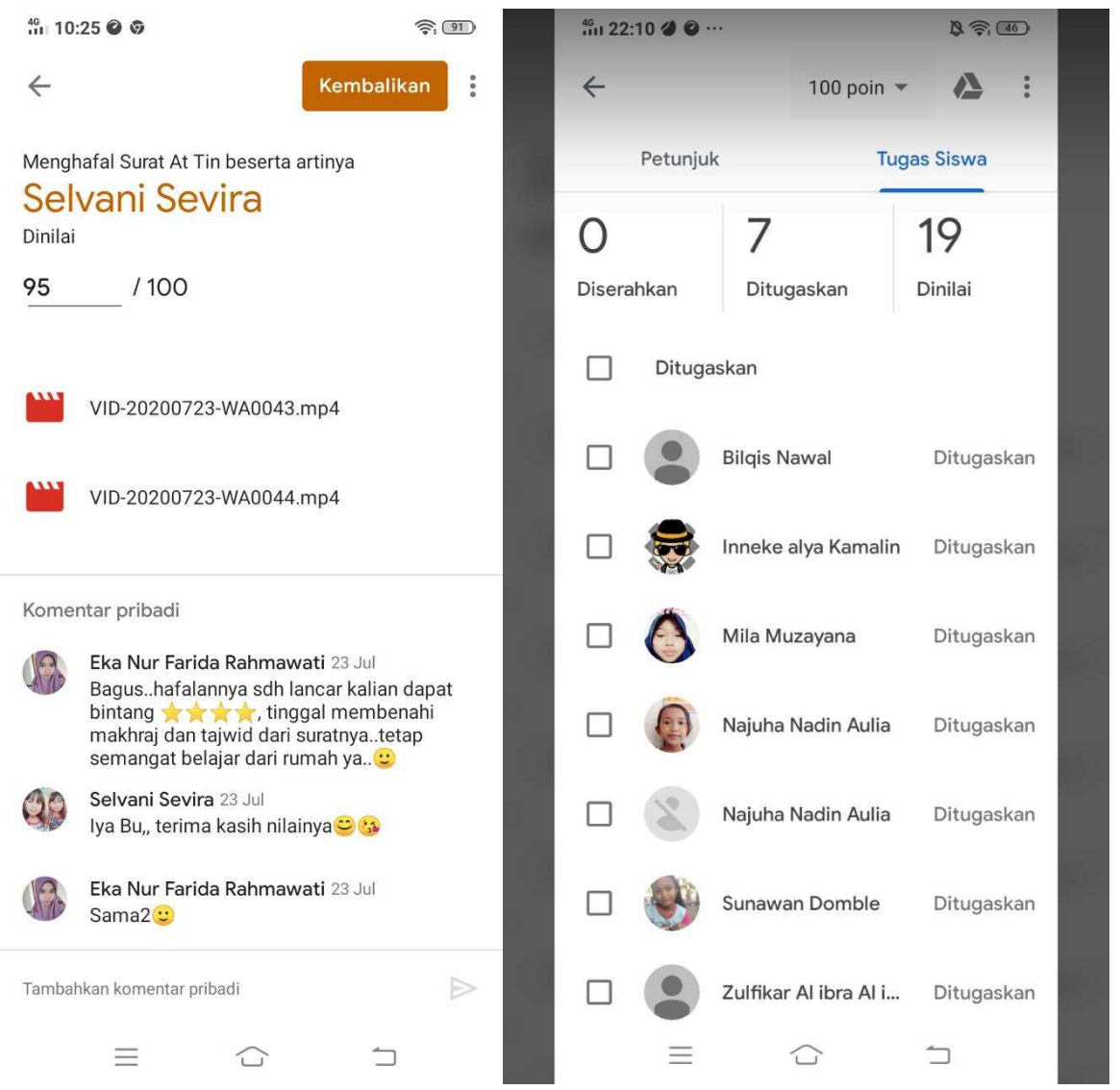

Gambar 4. Penerapan Google Classroom oleh Guru PAI

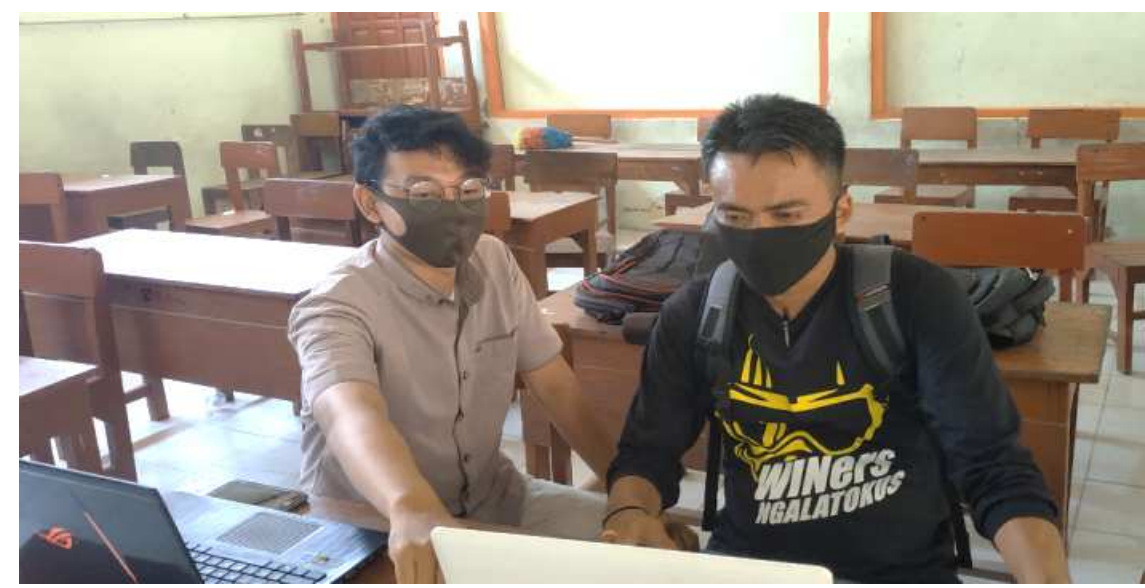

Gambar 5. Penerapan Google Classroom oleh Guru PJOK

Pada minggu kedua penerapan google classroom Guru PAI mengalami kesulitan terkait bahan materi yang diajarkan. Buku paket PAI yang ada sudah tidak relevan dengan Kompetensi Dasar (KD) yang diajarkan sesuai kurikulum terbaru. Selain itu, LKS mata pelajaran PAI juga belum dibagikan karena mengalami keterlambatan. Guru PAI memiliki ebook terbaru sebagai bahan ajar namun siswa kurang antusias jika materi melalui teks yang dibagikan.

Pembelajaran materi melalui video lebih diminati siswa sehingga pada minggu pertama penerapan Guru PAI menggunkan materi video yang 
di unduh melalui youtube. Guru PAI ingin membuat video materi sendiri, mahasiswa KKN 08 Back To Village 2020 memberikan penyuluhan aplikasi "PowerDirector" untuk edit video. Guru PJOK tidak mengalami kendala, beliau sudah bisa mengedit video pembelajaran sendiri dan LKS PJOK dibagikan.

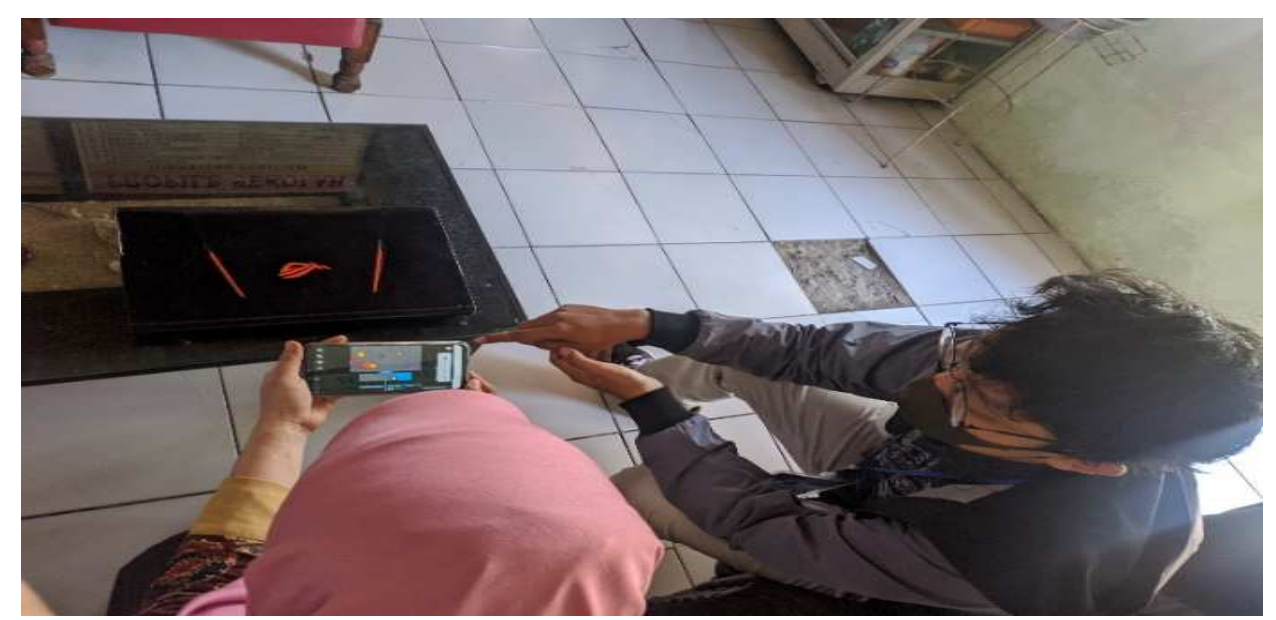

Gambar 5. Membuat Video Pembelajaran oleh Guru PAI

Guru PAI sudah bisa menambahkan video, foto, teks, lagu, suara rekaman sebagai bahan video. Pada proses mengedit video materi Guru PAI sempat mengalami kendala dalam mengatur suara backsound dengan suara rekaman, menyimpan video tidak sesuai durasi, dan merubah papan warna. Kendala tersebut didiskusikan melalui whatsapp dan dapat diselesaikan. Sehingga Guru PAI sudah bisa membuat video materi sendiri sesuai dengan kompetensi dasar yang disyaratkan.

Pada minggu ketiga penerapan google classroom dikolaborasi dengan pelaksanaan google meet sebagai media telekonferensi. Penerapan google meet pada minggu ini dilaksanakan untuk mereview materi minggu pertama dan kedua. Penerapan oleh Guru PAI pada kelas IV siswa diharuskan memakai baju muslim dan bersama-sama melakukan hafalan surat Al-falaq. Untuk percobaan pertama ini sebagian besar siswa masih malu-malu ketika ditanya tetapi setelah 15 menit siswa agak terbiasa dan mulai aktif berbicara. Selain itu, beberapa siswa juga mengalami kendala dalam sinyal sehingga ada yang lag, suara putus-putus. Percobaan pertama ini dihadiri 16 dari 34 siswa, karena memang sebagian besar Wali Murid menggunakan smartphone untuk kepentingan kerja. Secara umum penerapan google meet ini mengasikkan bagi siswa banyak yang antusias dapat bertatap muka dengan guru dan teman-teman sekelasnya. 


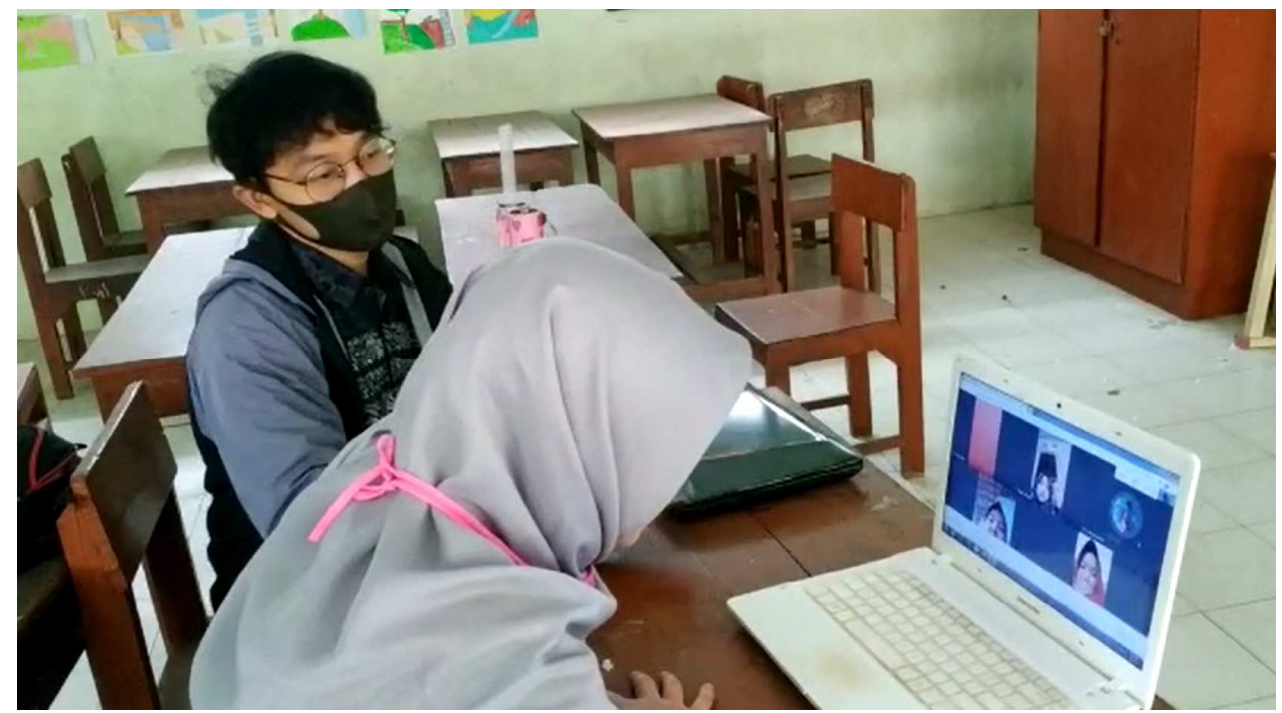

Gambar 6. Penerapan Google Meet oleh Guru PAI

\section{EVALUASI}

Pada tahap evaluasi, merupakan tahap akhir untuk mengetahui keberhasilan kegiatan yang telah dilaksanakan kepada sasaran dan dampaknya. Untuk mengetahui keberhasialan program maka harus memerinci aplikasi yang diterapkan. Pelaksanaan evaluasi ini dilakukan kepada Guru PAI, Guru PJOK, dan Siswa kelas 4.

Pelaksanaan program kerja penerapan aplikasi google classroom berdampak positif bagi Guru SDN Wonoayu. Penerapan aplikasi ini sangat membantu Guru PAI dan PJOK dalam melaksanakan kegiatan pembelajaran daring seperti upload materi, memeberi tugas, menilai dan merekap tugas. Hal tersebut terbukti dari nilai kuesioner yang telah diberikan dan diisi dengan sejujurnya. 

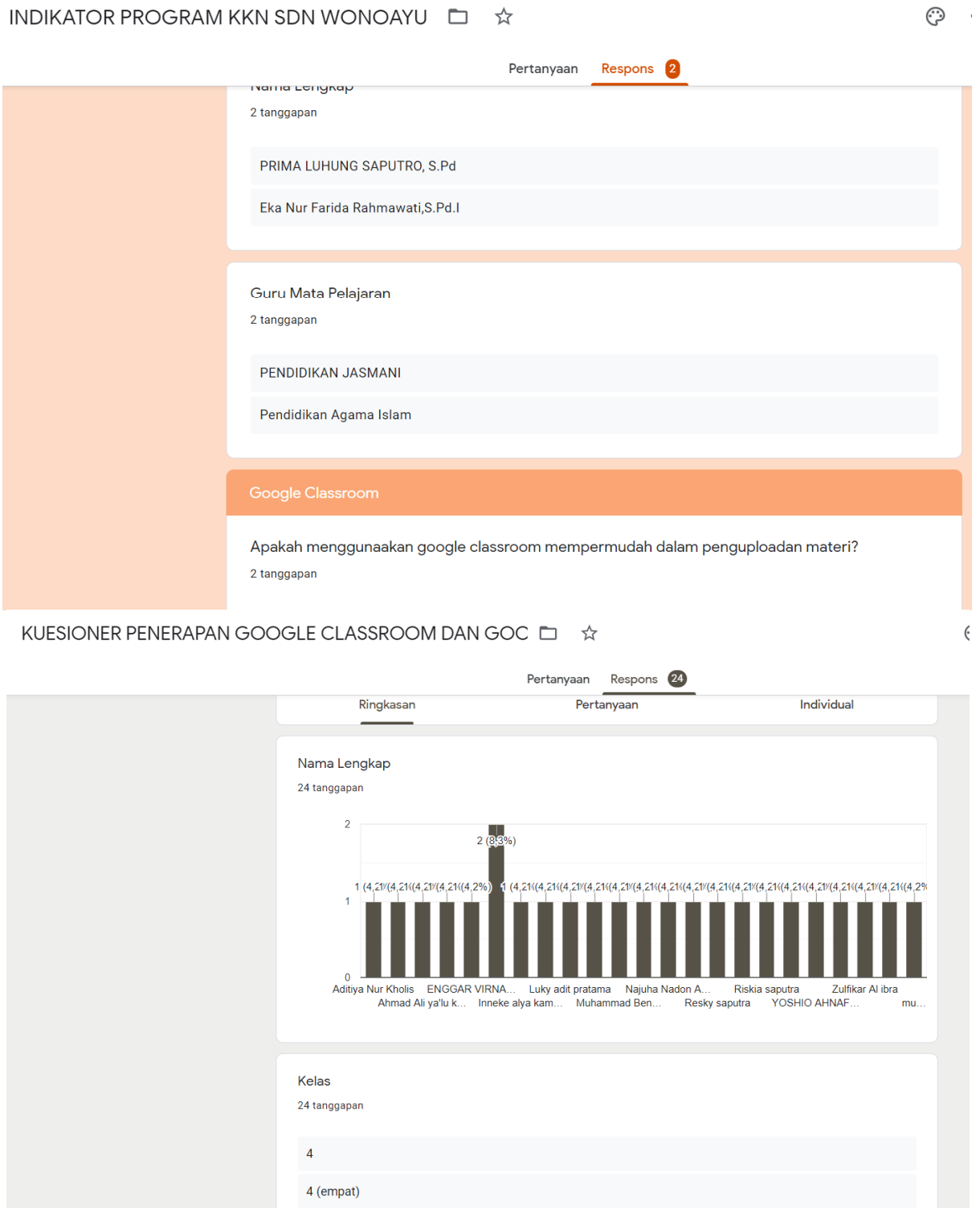

Gambar 6. Evaluasi Pelaksanaan melalui Google Forms 
Tabel 2. Evaluasi Penerapan Google Classroom oleh Guru Sasaran

\begin{tabular}{|c|l|c|c|}
\hline No & \multicolumn{1}{|c|}{ Pertanyaan } & Guru PAl & Guru PJOK \\
\hline 1 & $\begin{array}{l}\text { Apakah menggunaakan google } \\
\text { classroom mempermudah dalam } \\
\text { penguploadan materi? }\end{array}$ & 5 & 4 \\
\hline 2 & $\begin{array}{l}\text { Apakah menggunakan google } \\
\text { classroom materi lebih tertata? }\end{array}$ & 5 & 5 \\
\hline 3 & $\begin{array}{l}\text { Apakah menggunakan google } \\
\text { classroom tugas lebih tertata? }\end{array}$ & 5 & 5 \\
\hline 4 & $\begin{array}{l}\text { Apakah menggunakan google } \\
\text { classroom memberikan nilai pada } \\
\text { tugas lebih mudah? }\end{array}$ & 5 & 5 \\
\hline 5 & $\begin{array}{l}\text { Apakah menggunakan google } \\
\text { classroom lebih mudah untuk } \\
\text { merekap tugas? }\end{array}$ & 5 & 5 \\
\hline 6 & $\begin{array}{l}\text { Apakah menggunakan google } \\
\text { forms sebagai media } \\
\text { UH/kuis/UTS/UAS efektif? }\end{array}$ & 5 & 5 \\
\hline 7 & $\begin{array}{l}\text { Secara keseluruhan penerapan } \\
\text { google classroom apakah } \\
\text { berjalan lancar? }\end{array}$ & 4 & 5 \\
\hline
\end{tabular}

$\begin{array}{lll}\text { Keterangan : } & 1 & \text { Buruk Sekali } \\ 2 & \text { Buruk } \\ 3 & \text { Sedang } \\ 4 & \text { Baik } \\ 5 & \text { Baik Sekali }\end{array}$

Berdasarkan hasil kuesioner secara keseluruhan mendapatkan respon diatas sama dengan 4 berarti sudah memenuhi indikator keberhasilan $(\geq 3)$. Namun pada pelaksanaannya memang terdapat kendala tekait teknis yang dapat diselesaikan dengan pendampingan. Untuk kendala media perangkat yang kurang mempuni dapat menggunakan whatsapp grup dan yang tidak memiliki dapat menggunakan sistem paguyuban seperti Wali Kelas II SDN Wonoayu. Bagi siswa SDN Wonoayu pelaksanaan google classroom berdampak positif dalam berbagai aspek. Kuesioner ini diberikan kepada siswa kelas 4 SDN Wonoayu yang telah menerapkan google classroom. Berikut beberapa tanggapan sesuai aspek yang dilaksanakan : Keterangan :

$1=$ Buruk Sekali, 2 = Buruk, $3=$ Sedang, $4=$ Baik, $5=$ Baik Sekali 


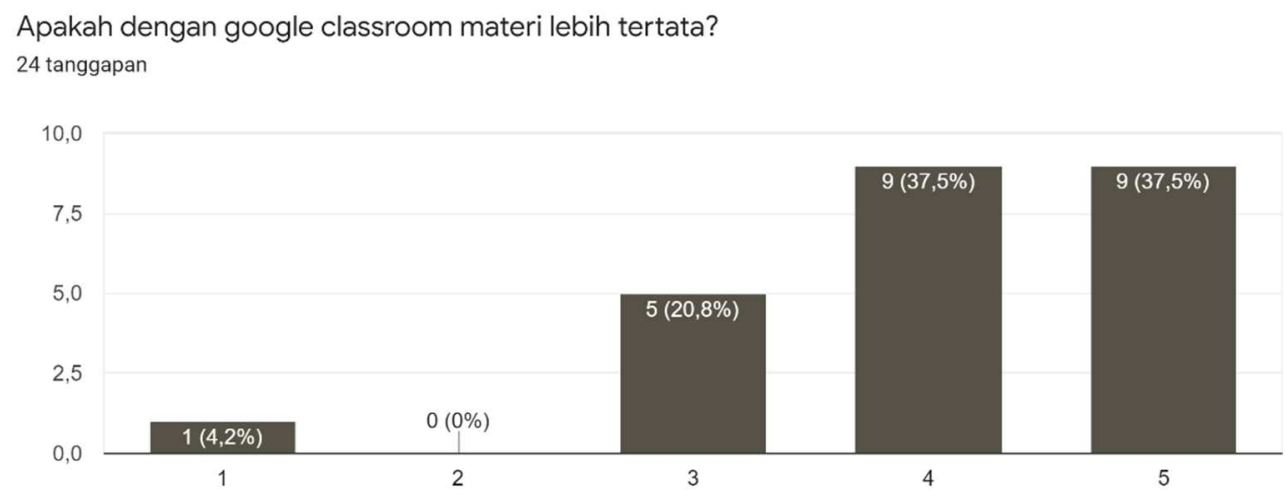

Gambar 7. Grafik Evaluasi Google Classroom Pertanyaan 1 oleh Siswa

Dalam aspek materi di google classroom siswa merasa lebih tertata dibandingkan dengan grup whatsapp sebesar 95,8\% memberi respon lebih dari sedang hal ini sudah memenuhi indicator keberhasilan $(>70 \%)$.

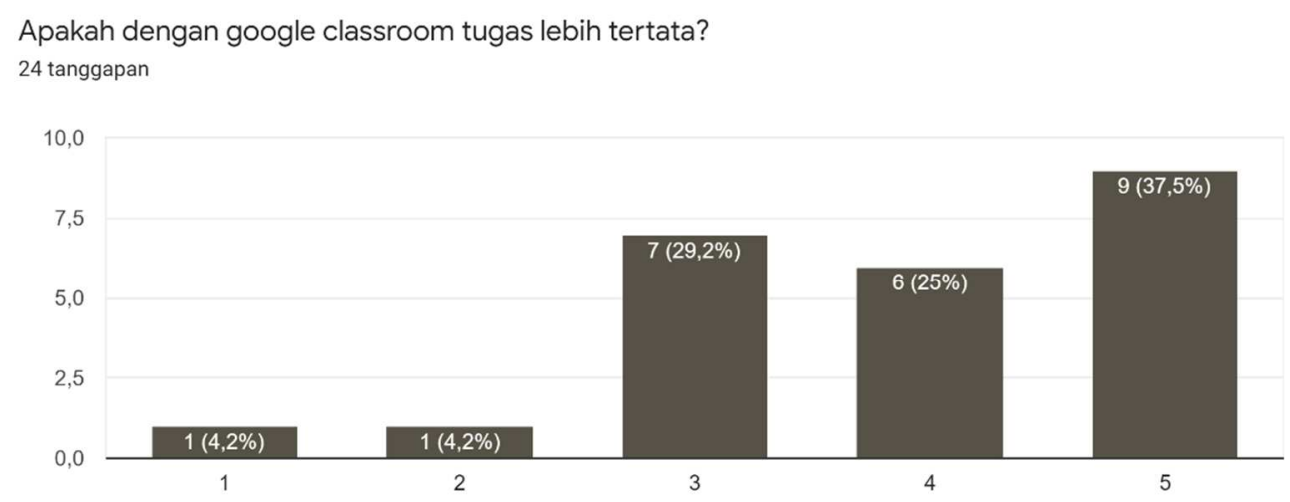

Gambar 8. Grafik Evaluasi Google Classroom Pertanyaan 2 oleh Siswa

Dalam aspek tugas google classroom siswa merasa lebih tertata dibandingkan dengan grup whatsapp sebesar $91,6 \%$ memberi respon lebih dari sedang hal ini sudah memenuhi indicator keberhasilan $(>70 \%)$. 


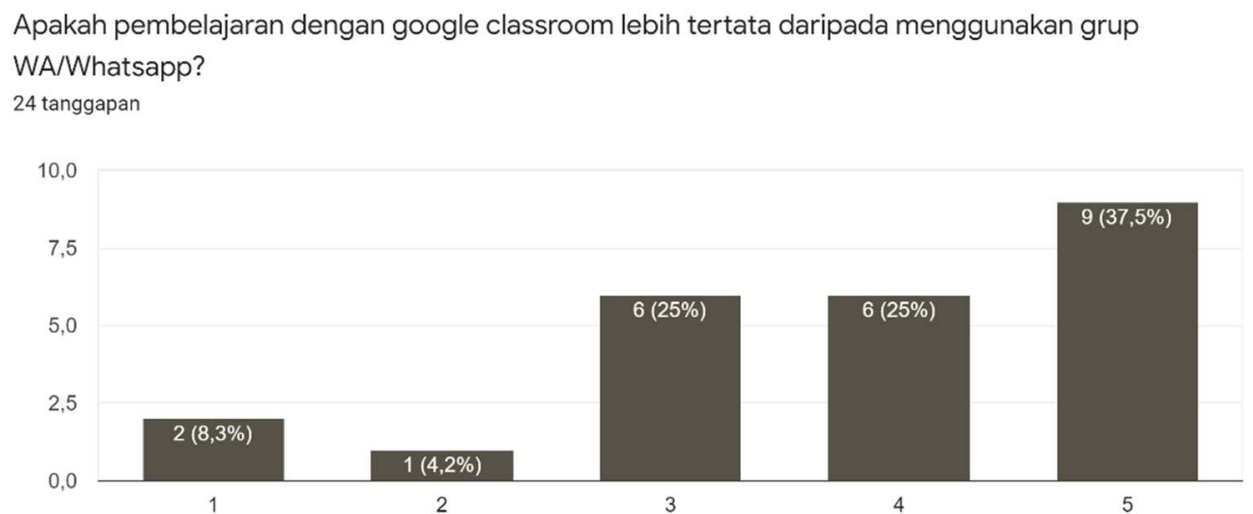

Gambar 9. Grafik Evaluasi Google Classroom Pertanyaan 3 oleh Siswa

Dalam aspek seluruh aspek pembelajaran meliputi materi, tugas, ujian, diskusi, dll di google classroom siswa merasa lebih tertata dibandingkan dengan grup whatsapp sebesar 87,5\% memberi respon lebih dari sedang hal ini sudah memenuhi indicator keberhasilan $(>70 \%)$.

Pelaksanaan program kerja penerapan aplikasi google meet juga berdampak positif bagi Guru SDN Wonoayu. Menggunakan aplikasi ini Guru PAI dan PJOK dapat bertatap muka langsung dengan murid untuk mereview materi sebelumnya dan sebagai media untuk praktek hafalan atau gerakan. Hal tersebut terbukti dari nilai kuesioner yang telah diberikan dan diisi dengan sejujurnya.

Tabel 3. Evaluasi Penerapan Google Meet oleh Guru Sasaran

\begin{tabular}{|c|l|c|c|}
\hline No & \multicolumn{1}{|c|}{ Pertanyaan } & Guru PAl & Guru PJOK \\
\hline 1 & $\begin{array}{l}\text { Apakah menggunakan google } \\
\text { meet untuk interaksi virtual } \\
\text { mereview materi/praktek } \\
\text { hafalan/praktek gerakan } \\
\text { meningkatkan pemahaman } \\
\text { siswa? }\end{array}$ & 5 & 5 \\
\hline 2 & $\begin{array}{l}\text { Apakah menggunakan google } \\
\text { classroom materi lebih tertata? }\end{array}$ & 4 & 5 \\
\hline
\end{tabular}

Keterangan :

$\begin{array}{ll}1 & \text { Buruk Sekali } \\ 2 & \text { Buruk } \\ 3 & \text { Sedang } \\ 4 & \text { Baik } \\ 5 & \text { Baik Sekali }\end{array}$

Berdasarkan hasil kuesioner secara keseluruhan mendapatkan respon diatas sama dengan 4 berarti sudah memenuhi indikator keberhasilan $(\geq 3)$. Namun pada pelaksanaannya memang terdapat kendala tekait teknis yang dapat diselesaikan dengan pendampingan. Kendala teknis meliputi sinyal lemah, percakapan kurang jelas, siswa masih belum 
kondusif dapat diatasi dengan mematikan video, mute audio, dan pendampingan. Bagi siswa SDN Wonoayu pelaksanaan google meet berdampak positif dalam berbagai aspek. Kuesioner ini diberikan kepada siswa kelas 4 SDN Wonoayu yang telah menerapkan google meet. Berikut beberapa tanggapan sesuai aspek yang dilaksanakan :

Keterangan :

$1=$ Buruk Sekali, $2=$ Buruk, $3=$ Sedang, $4=$ Baik, $5=$ Baik Sekali

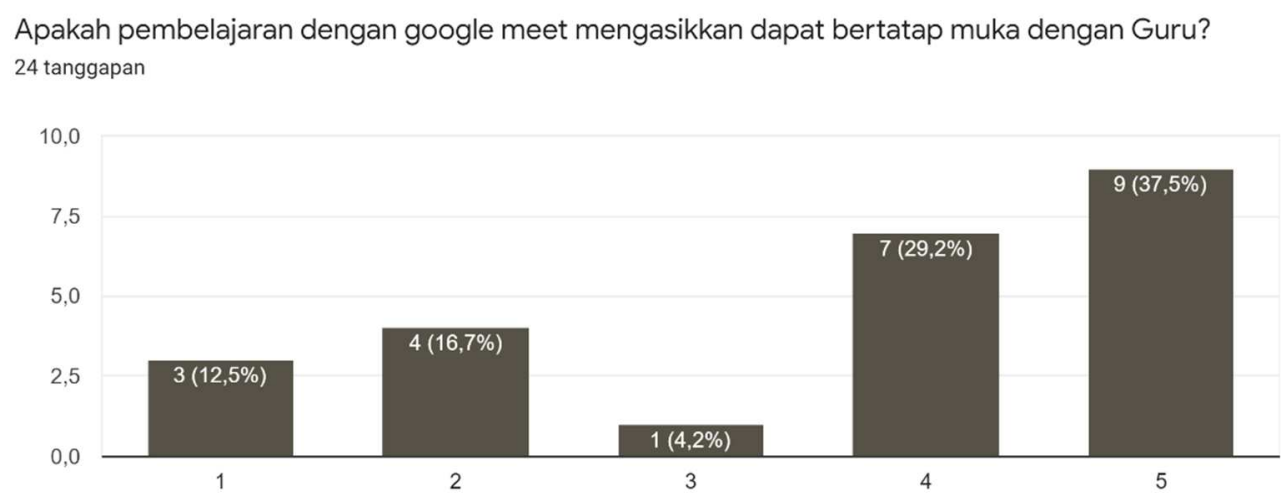

Gambar 10. Grafik Evaluasi Google Meet Pertanyaan 1 oleh Siswa

Dalam aspek kenyamanan menggunakan aplikasi google meet untuk bertemu guru, temen sekolah sebesar $70,9 \%$ memberi respon lebih dari sedang hal ini sudah memenuhi indicator keberhasilan( $>70 \%)$.

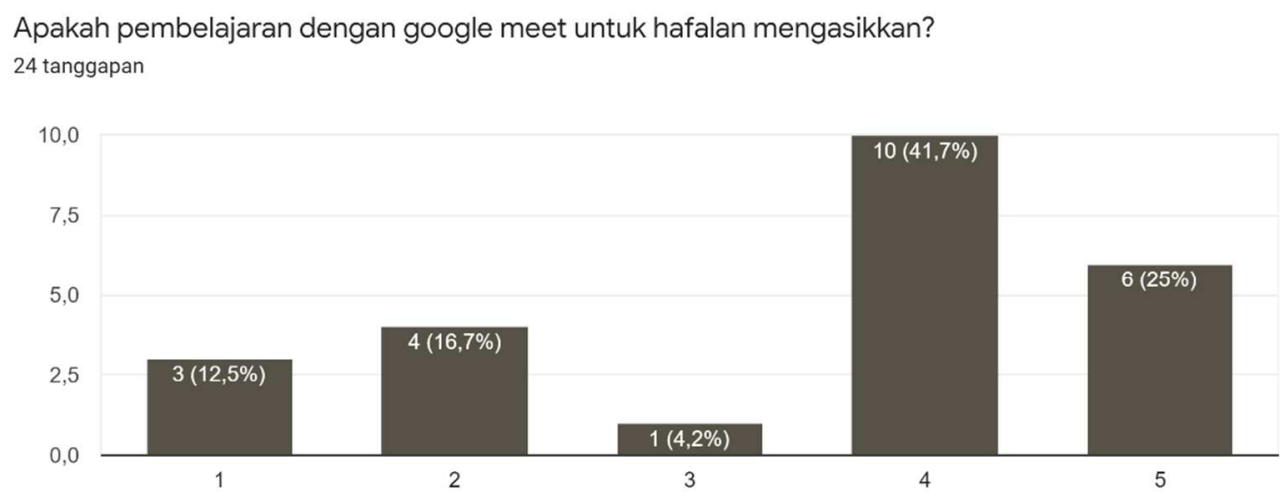

Gambar 11. Grafik Evaluasi Google Meet Pertanyaan 2 oleh Siswa

Dalam aspek penggunaan aplikasi google meet sebagai media praktek hafalan sebesar 70,9\% memberi respon lebih dari sedang hal ini sudah memenuhi indicator keberhasilan $(>70 \%)$. 


\section{KESIMPULAN}

Pelaksanaan KKN Back to Village UNEJ 2020 merupakan program baru menjadikan mahasiswa lebih dekat dengan lingkungan sekitar di daerah masingmasing dengan berbagai tematik yang sangat bermanfaat. Pada pelaksanaan program KKN yang telah dilakukan selama 45 hari telah menghasilkan perubahan Guru PAI dan PJOK SDN Wonoayu mampu menggunakan aplikasi google classroom dan google meet sebagai media pembelajaran. Secara keseluruhan program KKN ini dapat memenuhi indikator keberhasilan sebesar $>70 \%$ berdasarkan data kuesioner yang diberikan kepada Guru PAI, Guru PJOK, Sampel Siswa Kelas 4. Meskipun Kelas II SDN Wonoayu menggunakan sistem paguyuban wali murid untuk pembagian materi dan pengumpulan tugas, program ini dapat diterapkan dan berhasil di kelas lain. Seiring berjalannya waktu perlahan siswa dan guru memang harus dapat terus terbiasa menggunakan media pembelajaran ini sehingga pembelajaran daring dapat berjalan maksimal di pamdemi COVID-19.

\section{DAFTAR PUSTAKA}

Kemenkes. (15 Agustus 2020). Novel Coronavirus (2019 nCov) URL https://www.kemkes.go.id/folder/view/full-content/structure-faq.html.

Gugus Tugas Percepatan Penanganan Covid-19 (2020). Surat Edaran No. 4 Tahun 2020 tentang Kriteria Pembatasan Perjalanan Orang dalam Rangka Percepatan Penanganan Corona Virus Disease (COVID-19).

Aji, R.H.S., (2020). Dampak Covid-19 pada Pendidikan di Indonesia: Sekolah, Keterampilan, dan Proses Pembelajaran. Volume 7 No 5: 1-2.

Lutfianda, Ihyana.(22 Agustus 2020). Mahasiswa KKN UNEJ Penyuluhan Media Pembelajaran Daring Kepada Guru SDN Wonoayu URL https://www.kompasiana.com/ihlutfi/5f379172d541df52f75260f2/penyulu han-aplikasi-google-classroom-dan-google-meet-kepada-guru-sdnwonoayu-sebagai-media-pengumpulan-tugas-dan-telekonferensi. Diakses pada Agustus 2020. 